\begin{tabular}{|c|c|c|}
\hline \multirow{2}{*}{ IDUNAS } & NATURAL \& APPLIED SCIENCES & 2021 \\
& Vol. 4 \\
No. 1 \\
$(1-14)$ \\
\hline
\end{tabular}

\title{
Elemental Concentration and Physicochemical Properties of Soils under Different Landuses in Gashua a Sahel Region of Nigeria
}

\author{
Research Article \\ Busari, K. A..$^{*(D)}$, Alhassan, I. $^{* \text { (D) }}$, Onuk, O. G. ${ }^{{ }^{*}(D)}$ \\ ${ }^{l}$ Department of Physics, Federal University Gashua, Yobe State, Nigeria \\ ${ }^{2}$ Department of Agronomy, Federal University Gashua, Yobe State, Nigeria \\ Author E-mails \\ ialhassand@gmail.com \\ *Correspondance to: Alhassan, I., Department of Agronomy, Federal University Gashua, Yobe State, Nigeria. \\ DOI: 10.38061/idunas.815402
}

Received: 23.10.2020; Accepted: 25.01.2021

\section{Abstract}

Soil elements assessment under various land uses is vital in knowing the status of the soils in terms of fertility and toxicity. Therefore, a study was conducted to investigate some elements concentrations of soils under three different land uses in Gashua, Yobe State, Nigeria. Samples were randomly taken at 0-15 and $15-30 \mathrm{~cm}$ soil depth intervals from land uses. The land uses are Dry upland (DU), Lowland (LL) and Residential area (RA). The selected elements were determined in the laboratory using Atomic Absorption Spectrophotometer (AAS), while some physicochemical properties were determined using routine soil analysis methods. The results indicated significantly higher concentrations of Iron $\left(6.96 \mathrm{mg} \mathrm{kg}^{-1}\right)$, Manganese (3.12 $\mathrm{mg} \mathrm{kg}^{-1}$ ) and clay content (12.88\%), except for Nickel which was higher in DU (2.36 mg $\left.\mathrm{kg}^{-1}\right)$ but at par with the content in LL (2.04 mg kg-1) land use. There was no significant difference within the following soil elements within the study location: Cadmium $(\mathrm{Cd})$, Chromium $(\mathrm{Cr})$, Copper $(\mathrm{Cu})$ and Lead $(\mathrm{Pb})$ were below detection limit within the soils of the chosen land use types. Generally the soils textural class is sandy loam with higher mean bulk density $\left(1.62 \mathrm{~g} \mathrm{~cm}^{-3}\right)$ and a neutral soil $\mathrm{pH}(6.81)$. The physicochemical properties and elements investigated didn't show significant differences with soil depth. The basic elemental concentrations within the soils were mostly adequate for crop production, except Zn, with little variability within the landuse. They were generally below the utmost ecological risk permissible level set by WHO and FAO.

Keywords: Gashua, land use, soil texture, trace elements.

\section{INTRODUCTION}

Soil as a non-renewable resource and dynamic nature is prone to rapid degradation with land misuse (Eswaran et al., 2001). Land use is defined as the type of activities to which land is subjected to, including the inputs added, manipulation and management practices employed to produce, utilize and preserve (Ufot et al., 2016). Judicious land use is a principal factor underlying sustained agricultural production, maintenance and enhancement of the productive potential and life-support processes of natural resources 
(Srivastava et al., 1993). Different land uses, because of the different activities taking place on them may impact the soils physico-chemical properties differently, which may also require different management strategies. The physical properties of soils determine their adaptability to cultivation and the level of chemical and biological activity in the soil. Soil physical properties affect to a large extent soil water content and air for proper growth of plants. Soil physical properties can also be affected greatly by changes in land use systems and management practices (Tilahun, 2007; Sanchez, 1976).

Properties such as soil texture, structure, bulk density, porosity, moisture content and retention capacity are among the common soil physical properties. Soil texture refers to the relative percentage of sand, silt and clay within a soil layer and Bulk density is an indicator of soil compaction and reflects the soil ability to function for structural support, water and solute movement, and soil aeration (Arshad et al., 1996). Soil texture is an important aspect because it affects other physical and chemical properties such as water holding capacity and base saturation. It is also the primary factor determining the vertical distribution pattern and storage of carbon, nitrogen and phosphorus in savanna soils (Tabor et al., 2017). Bulk density is another physical property of soil that has a great influence on the soil porosity and compaction. It may cause restrictions to root growth and poor movement of air and water through the soil (Weil and Brady, 2017).

Elements are released overtime due transformations and various reactions of some minerals in the soil inherited from the parent materials. These elements perform different functions, some are essential in plant and animal nutrition, while others, their roles are not link to nutrition and their presence above known safe limits may endanger the environment as well as both plant and animal health (Weil and Brady, 2017). Elements like Cobalt $(\mathrm{Co})$ Copper $(\mathrm{Cu})$, Iron $(\mathrm{Fe})$, Manganese $(\mathrm{Mn})$, Nickel (Ni) and Zinc $(\mathrm{Zn})$ are considered essential in plant and animal nutrition while, Cadmium $(\mathrm{Cd})$, Chromium $(\mathrm{Cr})$ and Lead $(\mathrm{Pb})$ are not considered essential in their nutrition (Weil and Brady, 2017).

Timely and periodic assessment of the impact of land uses on elemental availability, distribution and ecological risks is indispensible for sustainable management of the soils of any area. The study is exploratory due to lack of information on background concentrations of the elements in soils of the study area. The objective of the study is to evaluate the concentrations of $\mathrm{Cd}, \mathrm{Co}, \mathrm{Cr}, \mathrm{Cu}, \mathrm{Fe}, \mathrm{Mn}, \mathrm{Ni}, \mathrm{Pb}$ and $\mathrm{Zn}$ in soils within three land use types in Gashua, Yobe State, Nigeria.

\section{MATERIALS \& METHODS}

\section{Description of the Study Area}

The study was conducted at Gashua in Bade Local Government Area of Yobe State, Northeast Nigeria. It is situated $190 \mathrm{~km}$ North West of Damaturu, the State Capital. It is located between longitudes $9^{\circ} 00^{\prime}$ and $10^{\circ} 30^{\prime} \mathrm{N}$ and latitudes $9^{\circ} 30^{\prime}$ and $10^{\circ} 30^{\prime} \mathrm{E}$ and at an altitude of 293 meters above sea level. The area is situated in the Sahel savanna agro-climatic zone with a unimodal rainfall pattern of an average annual rainfall of 300 - $430 \mathrm{~mm}$ and maximum rain is received between August and September. The annual mean minimum and mean maximum temperatures at the study area are 12 and $44^{\circ} \mathrm{C}$ respectively.

\section{Land Use Types}

Three land use types' namely dry upland arable farms (arable crops such as millet, cowpea, sesame, sorghum etc. are grown), lowland farms along the floodplains of river Yobe (vegetables, rice and wheat are the common crops cultivated in these areas) and residential area (inhabited by human settlements) were studied in Gashua in Bade Local Government Area of Yobe State, Nigeria. 


\section{Soil Sample Collection}

Stratified random-composite sampling design was adopted for the survey. Three representative soil samples were collected randomly using a soil auger from each of the four replicate of each land use type at two soil depths of $0-15 \mathrm{~cm}$ and $15-30 \mathrm{~cm}$. The samples per replicate per depth were composite for laboratory analysis. Sampling cylinders were also used in taking undisturbed samples from each replicate closer to auger sampling points for bulk density determination (Estefan et al., 2013). The augured soil samples were then air-dried at room temperature for 5 days, sieved before analysis.

\section{Soil Analysis}

The soil properties analyzed include soil particle size distribution (PSD), bulk density (BD), pH, Cobalt (Co), Cadmium (Cd), Chromium (Cr), Copper (Cu), Iron (Fe), Manganese (Mn), Nickel (Ni), Lead (Pb) and Zinc (Zn). Soil particle size distribution was determined by the hydrometric method (Estefan et al., 2013). Soil bulk density was determined by the undisturbed soil core sampling method. The soil samples were dried in an oven at $104^{\circ} \mathrm{C}$ to constant weights and calculated as:

$$
\mathrm{BD}\left(\mathrm{g} \mathrm{cm}^{-3}\right)=\frac{W}{V}
$$

Where: $\mathrm{W}=$ weight of oven dry soil $(\mathrm{g})$ and $\mathrm{V}=$ volume of soil sample $\left(\mathrm{cm}^{-3}\right)$. The $\mathrm{pH}$ of the soils was measured in a 1:2 (soil: water) suspension potentiometrically using digital pH meter (Estefan et al., 2013).

Soil samples were digested using Nitric-sulphuric-perchloric acid digestion method as modified from Idera et al (2015). Five gram of soil samples were measured into $125 \mathrm{ml}$ Beaker and a mixture of $2 \mathrm{ml}, 4 \mathrm{ml}$ and $25 \mathrm{ml}$, of concentrated $\mathrm{H}_{2} \mathrm{SO}_{4}, \mathrm{HClO}_{4}$ and $\mathrm{HNO}_{3}$ were added respectively for digestion on a hot plate in a fumes hood. The digested sample was allowed to cool at room temperature and $50 \mathrm{ml}$ of deionized water was added and then filtered through a $0.45 \mu$ Millipore membrane filter paper. The filtered samples were then made up to $100 \mathrm{ml}$ with deionized water. The concentration of the selected elements $(\mathrm{Cd}, \mathrm{Co}, \mathrm{Cr}, \mathrm{Cu}$, $\mathrm{Fe}, \mathrm{Mn}, \mathrm{Ni}, \mathrm{Pb}$ and $\mathrm{Zn}$ ) were then determined from the extract with Atomic Absorption Spectrophotometer (PerkinElmer 900T Boston, USA) using appropriate lamp.

\section{Statistical Analysis}

The analyzed data from the laboratory tests were subjected to descriptive statistics and analysis of variance technique using $\mathrm{R}$ version 3.6.1 statistical package. Differences among the means were separated using HSD criterion at 5\% significance level (R, 2019)

\section{RESULTS \& DISCUSSION}

The summary statistics of the soil properties determined were presented in Table 1. The results indicated normally distribution for the variables tested except for clay (1.47) and Mn (1.82) which were positively skewed. The means of the soil properties were not far from their median values; this indicated existence of very few outliers or none. The Coefficient of variation of the soil properties were low for soil $\mathrm{pH}(6.76 \%), \mathrm{BD}(7.85 \%)$, sand (8.63\%), Fe (9.03\%), Zn (11.37\%); moderate for Silt (28.80\%) and higher in clay (38.56\%), Co (48.66\%), Mn (66.70\%) and $\mathrm{Ni}(77.15 \%)$ according to the ratings in Tabi and Ogunkunle (2007). This revealed considerable variability as such site-specific management may be required. 
Table-1. Descriptive Statistics of the Mean values of the Physico-chemical Properties and Elemental Concentrations in the Soils of the Study Areas

\begin{tabular}{lccccccccc}
\hline Variables & Min & Max & Mean & Median & IQR & SD & SEM & CV (\%) & Skewness \\
\hline Sand $(\%)$ & 61.00 & 88.00 & 76.00 & 76.00 & 8.50 & 6.56 & 1.34 & 8.63 & -0.24 \\
Silt $(\%)$ & 7.00 & 21.00 & 14.00 & 14.00 & 6.50 & 4.03 & 0.82 & 28.80 & 0.08 \\
Clay $(\%)$ & 4.00 & 23.00 & 10.00 & 9.50 & 4.00 & 3.86 & 0.79 & 38.56 & 1.47 \\
$\mathrm{BD}\left(\mathrm{g} \mathrm{cm}^{-3}\right)$ & 1.38 & 1.85 & 1.62 & 1.66 & 0.12 & 0.13 & 0.03 & 7.85 & -0.57 \\
$\mathrm{pH}$ & 6.13 & 7.86 & 6.81 & 7.73 & 0.63 & 0.46 & 0.09 & 6.76 & 0.66 \\
$\mathrm{Co}\left(\mathrm{mg} \mathrm{kg}^{-1}\right)$ & 0.01 & 0.38 & 0.20 & 0.22 & 0.14 & 0.10 & 0.02 & 48.66 & -0.16 \\
$\mathrm{Mn}\left(\mathrm{mg} \mathrm{kg}^{-1}\right)$ & 0.48 & 5.46 & 1.89 & 1.72 & 0.98 & 1.26 & 0.26 & 66.70 & 1.82 \\
$\mathrm{Ni}\left(\mathrm{mg} \mathrm{kg}^{-1}\right)$ & 0.06 & 4.59 & 1.74 & 2.10 & 2.18 & 1.34 & 0.27 & 77.15 & 0.39 \\
$\mathrm{Fe}\left(\mathrm{mg} \mathrm{kg}^{-1}\right)$ & 5.79 & 7.89 & 6.69 & 6.57 & 0.81 & 0.60 & 0.12 & 9.03 & 0.42 \\
$\mathrm{Zn}\left(\mathrm{mg} \mathrm{kg}^{-1}\right)$ & 0.68 & 1.22 & 0.95 & 0.97 & 0.10 & 0.11 & 0.02 & 11.37 & -0.18 \\
$\mathrm{Cd}$ & ND & ND & ND & ND & & & & & \\
$\mathrm{Cr}$ & ND & ND & ND & ND & & & & & \\
$\mathrm{Cu}$ & ND & ND & ND & ND & & & & & \\
$\mathrm{Pb}$ & ND & ND & ND & ND & & & & & \\
\hline
\end{tabular}

$\mathrm{Min}=$ minimum, Max = maximum, $\mathrm{IQR}=$ interquartile range, $\mathrm{SD}=$ standard deviation, $\mathrm{SEM}=$ standard error of the mean, $\mathrm{CV}$ $=$ coefficient of variation.

The soil particle size distribution (PSD) showed that the sand and silt fractions did not significantly differ among land use types (Figure 1 and 2 respectively). The overall mean of the clay fraction was found to be significantly higher in the Lowland (12.88\%) compared to Dry upland $(8.61 \%)$ and Residential area $(8.50 \%)$ (Figure 3). High clay content in Lowland may presumably be due to the physiographic location of Lowland and the nature of the erosional sediments deposited and intensive soil management practices that promote further weathering processes could be a possible reason for higher clay content (Negasa et al., 2017). The dominant soil textural class (Sandy loam) throughout the study area indicates the homogeneity of soil forming processes and the similarity of parent materials. Soil bulk density was also not significantly affected by land use effects (Figure 4). The highest $\left(1.67 \mathrm{~g} \mathrm{~cm}^{-3}\right)$ mean value of soil bulk density was recorded under cultivated lowland area (LL) and the lowest $\left(1.57 \mathrm{~g} \mathrm{~cm}^{-3}\right)$ mean BD was found in Dry Upland (DU). Similar mean bulk density value $\left(1.63 \mathrm{~g} \mathrm{~cm}^{-3}\right)$ was also reported for soils of Bade LGA in Yobe State, Nigeria by Alhassan et al. (2018). The average bulk densities recorded in the study area are marginally high for crop growth, because it was reported that for optimum movement of air and water through the soil, it is generally desirable for the soil to have a BD of $<1.5 \mathrm{gcm}^{-3}$ and that in general bulk densities greater than $1.6 \mathrm{gcm}^{-3}$ tend to restrict root growth (Hunt and Gilkes, 1992; McKenzie et al., 2004). The high bulk density recorded could be attributed to the high sand content of the soils as was reported that sand content have a greater effect on bulk density than other soil properties (Chaudhari et al., 2013). This was further substantiated by Lal (2006) who reported that normal range of bulk densities for clay is 0.90 to $1.40 \mathrm{gcm}-$ 3 and a normal range for sand is 1.40 to $1.90 \mathrm{gcm}-3$ with potential root restriction occurring at $\geq 1.40 \mathrm{gcm}-$ 3 for clay and $\geq 1.60 \mathrm{gcm}-3$ for sand.

Soil $\mathrm{pH}$ showed little variability across the land uses with a mean value of 6.81 and ranged from 6.57 to 6.95 (Figure 5), the soils are then categorized as neutral (6.51 to 7.5) by Weil and Brady (2017). Soil pH is an important secondary determinant of nutrients availability and transport as it affects their water solubility in the soil. The $\mathrm{pH}$ values of 6.5 to 7.5 is considered ideal for crop production (Estefan et al., 2013) therefore, the soil $\mathrm{pH}$ values of the study area is considered good for crop production and will not require any amendment. 


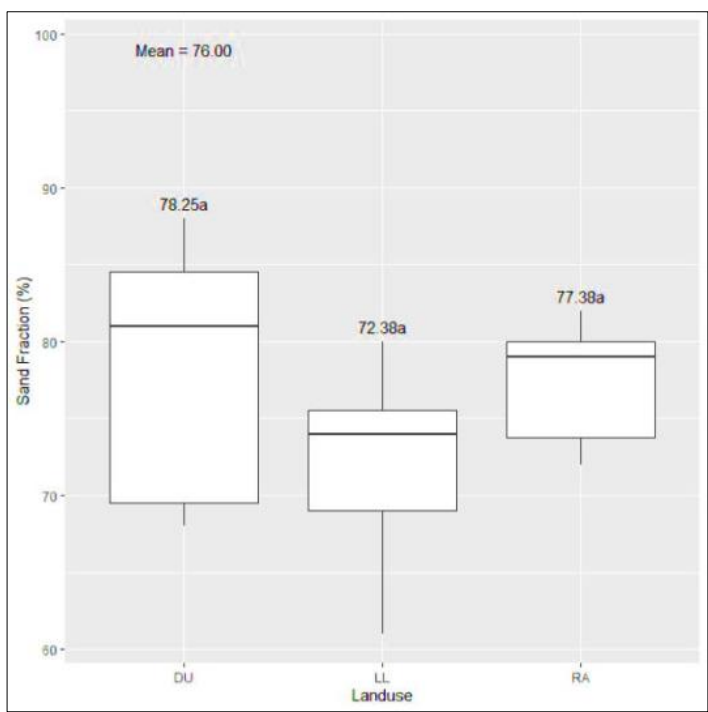

Figure-1. Sand Fraction Distribution of the Soils

Under Landuse types (Dry Upland Farm (DU),

Lowland Farm (LL) and Residential Area (RA)

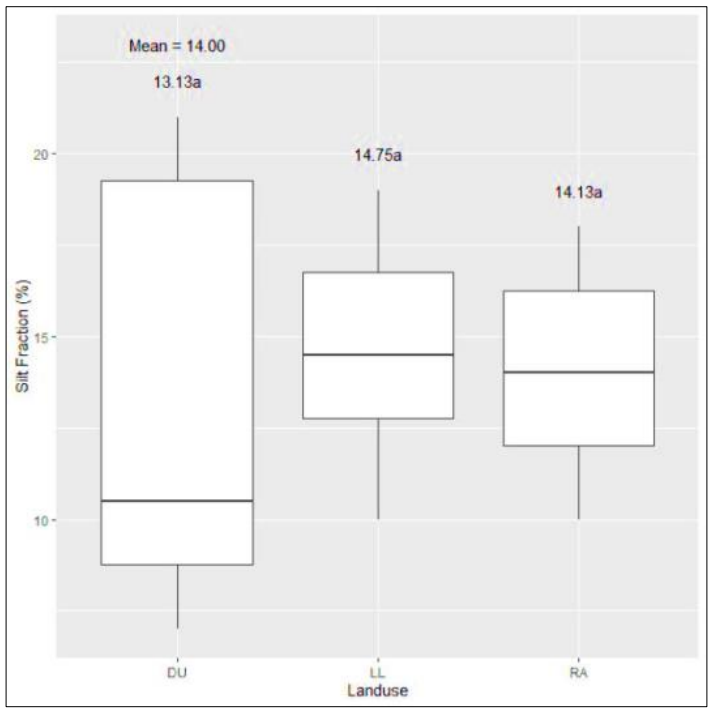

Figure-2. Silt Fraction Distribution of the Soils under Landuse types (Dry Upland Farm (DU), Lowland Farm (LL) and Residential Area (RA) 


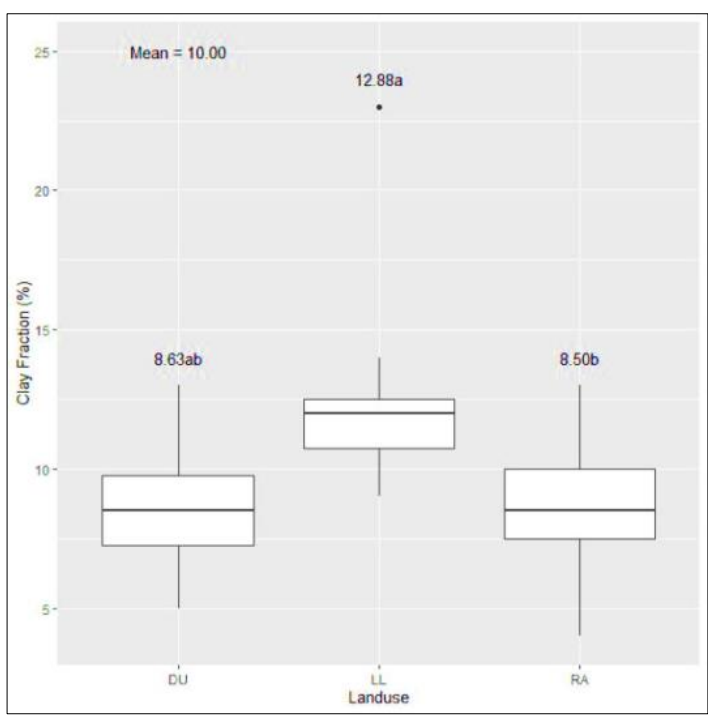

Figure-3. Clay Fraction Distribution of the Soils under Landuse types (Dry Upland Farm (DU), Lowland Farm (LL) and Residential Area (RA)

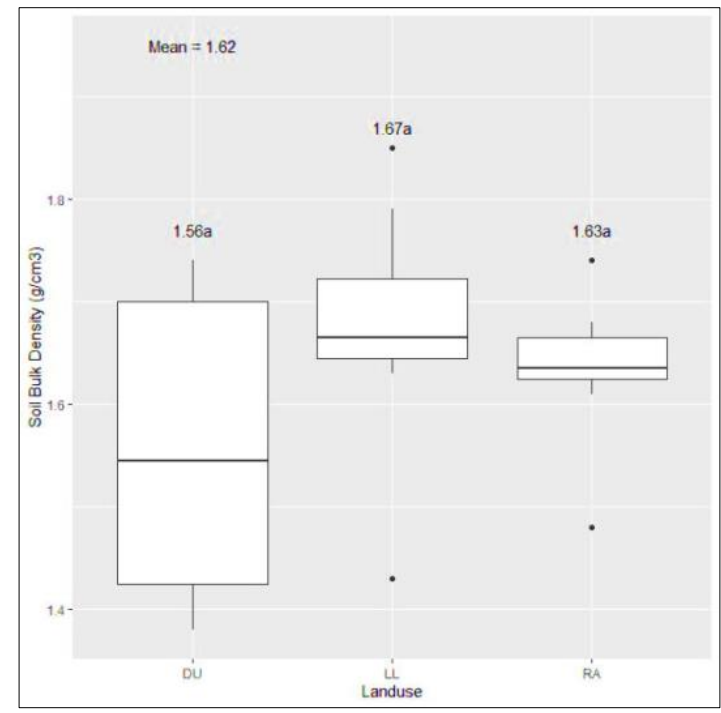

Figure-4. Bulk Density $\left(\mathrm{g} \mathrm{cm}^{-3}\right)$ of the Soils under Landuse types (Dry Upland Farm (DU), Lowland Farm (LL) and Residential Area (RA) 


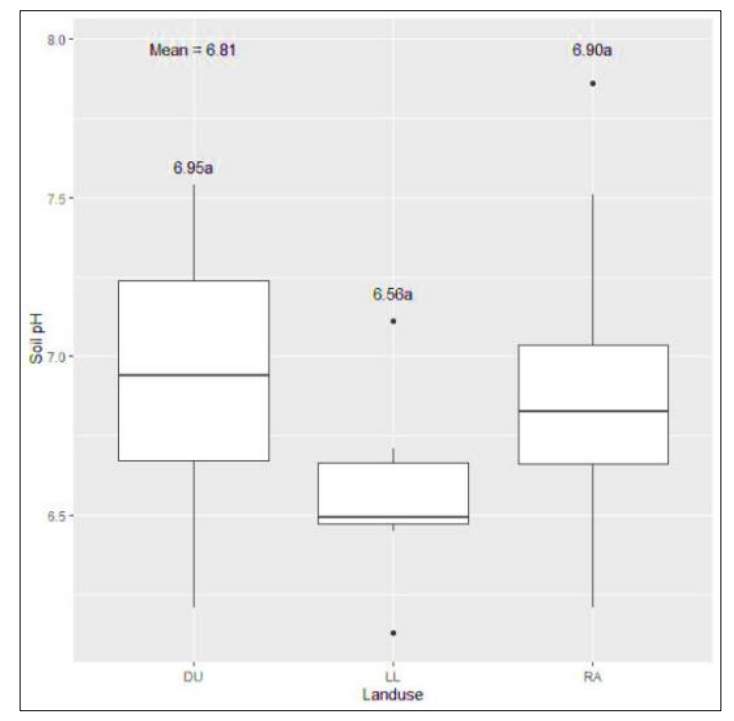

Figure-5. pH of the Soils under Landuse types

(Dry Upland Farm (DU), Lowland Farm (LL) and Residential Area (RA))

The mean elemental concentrations $\left(\mathrm{mgkg}^{-1}\right)$ in the soils of the land use types were presented in Figures 6 to 10. Result showed that Cobalt (Co) was not significantly different between the land uses (Figure 6). Cobalt is considered an essential nutrient in trace amounts for ruminant animals, largely due its requirement for rumen bacteria, atmospheric $\mathrm{N}_{2}$-fixation by microorganisms and for plants (Ma and Hooda, 2010). A concentration of Co (4.6-9.1 $\mathrm{mgkg}^{-1}$ ) was reported for some soils in Nigeria (Agbenin et al., 2009). The mean concentration of Co recorded at the study sites were below the WHO/FAO (2001) ecological risk permissible limit of $100 \mathrm{mgkg}^{-1}$ for soils.

The mean concentration of iron (Fe) ranged from 6.23 to $6.96 \mathrm{mgkg}^{-1}$ with a mean value of $6.69 \mathrm{mgkg}^{-}$ ${ }^{1}$ (Table 1). The result indicated significant difference between the land uses with high concentration in LL which was at par with RA and lower in DU (Figure 7). The mean concentration of Fe recorded was above the critical limit (>5 $\mathrm{mgkg}^{-1}$ ) for crop production (Esu, 1991) and below the FEPA (1991) guidelines for heavy metals in soils ecological risk threshold value of $400.00 \mathrm{mgkg}^{-1}$. In agreement to our findings Mulima et al. (2015) reported higher values of Fe for the soils of similar agro-ecological zone and Munkholm et al. (1993) reported that Fe and Mn deficiencies in tropical Africa are rare. The high mean Fe content in the soil indicates that Fe deficiency is not likely for crops grown on these soils. However, the presence of Fe in high concentrations in soils could lead to the formation of phlintite upon complex chemical reactions Plinthosols are more common type of soils in the wetter parts of the Sahel and are always rich in iron (Decker's et al, 1995).

Significantly higher Mn concentration (3.12 $\mathrm{mg} \mathrm{kg}^{-1}$ ) was recorded in LL and lower at DU (1.12 mg $\mathrm{kg}^{-1}$ ) at par with RA (1.41 mg kg-1) (Figure 8). The mean value (1.88 $\mathrm{mg} \mathrm{kg}^{-1}$ ) indicated moderate availability for crop production (Esu, 1991; Shukla and Gupta, 1975). It was further supported by Horneck et al. (2011) that soil test values for Mn of between 1 and $5 \mathrm{ppm}$ are usually sufficient for crop production. In contrast Mulima et al. (2015) reported a very high mean value of Mn (10.23 $\left.\mathrm{mgkg}^{-1}\right)$ for the soils of similar environment in Nigeria.

Although the concentration of Iron and Manganese recorded are adequate for crop production, the

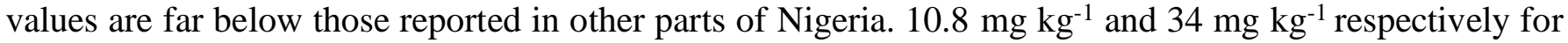
Fe and Mn were reported for soils of Northern Guinea Savanna region of Nigeria by Mustapha et al. (2011), $19.6 \mathrm{mg} \mathrm{kg}^{-1}$ for Fe in Sudan Savanna by Oyinlola and Chude (2010), $22.5 \mathrm{mg} \mathrm{kg}^{-1}$ and $21.5 \mathrm{mg} \mathrm{kg}^{-1}$ for soils of Bauchi, northern guinea Savanna (Oluwadare et al., 2013) and $14.48 \mathrm{mg} \mathrm{kg}^{-1}$ and $17.59 \mathrm{mg} \mathrm{kg}^{-1}$ for soils of Billiri, northern guinea Savanna of Nigeria (Ibrahim et al., 2011). This could be attributed to the neutral $\mathrm{pH}$ in where the availability of $\mathrm{Fe}$ and $\mathrm{Mn}$ tend to be low. It was reported that with increase in soil 
$\mathrm{pH}$ decreases the solubility of most trace elements, which often leads to their low concentrations in soil solution (Kabata-Pendias, 2011).

Nickel is an essential micro nutrient for plants and is equally important to animals. As with other trace metals, elevated $\mathrm{Ni}$ concentrations in soils have potential negative impact on plants, microorganisms and animals (Ma and Hooda, 2010). The mean concentrations of nickel recorded in the soil samples ranged from 0.80 to $2.36 \mathrm{mgkg}^{-1}$ with a mean value of $1.73 \mathrm{mgkg}^{-1}$ (Figure 9). This value is lower than 12.6-25.7 $\mathrm{mg} \mathrm{kg}^{-1}$ reported for some soils in northern Nigeria (Agbenin et al., 2009) and Ogundele et al. (2015) reported $1.83-14.87 \mathrm{mgkg}^{-1}$ as the mean concentration of $\mathrm{Ni}$ in soil for North Central Nigeria. The mean concentrations of Ni recorded from the studied land uses were below the WHO/FAO (2001) permissible limit of $50 \mathrm{mgkg}^{-1}$ for soils. Large variability of $\mathrm{Ni}$ could be attributed to spatial variability in the sampling points within the lowland area as reported that micronutrient content in the soil often shows considerable spatial variation (Hengl et al., 2017), while the low mean value may be due to high $\mathrm{pH}$ level of the soils. The Ni concentration in soils of the studied area may not pose environmental problem and is above lowest required level $\left(<0.5 \mathrm{mgkg}^{-1}\right)$ for plant nutrition (Guodong et al, 2020).

The mean concentration of zinc ( $\mathrm{Zn}$ ) ranged from 0.90 to $0.98 \mathrm{mgkg}^{-1}$ with a mean value of $0.95 \mathrm{mgkg}^{-}$ ${ }^{1}$ (Figure 10). This is in agreement with Mulima et al. (2015) who reported low mean Zn status (0.85 $\mathrm{mgkg}^{-}$ $\left.{ }^{1}\right)$ for the soils of Geidam in Yobe State, Nigeria and lower than the mean value of $3.00 \mathrm{mgkg}^{-1}$ recorded for Kano urban agricultural lands in Nigeria (Dawaki et al., 2013) and $31.17 \mathrm{mgkg}^{-1}$ for some soils in South Western Nigeria (Adagunodo et al., 2018). Zinc deficiency was also reported that it predominates the list of micronutrients that are deficient in sub Saharan African arable soils (Kihara et al., 2020), therefore crops like rice and maize that are susceptible to $\mathrm{Zn}$ deficiency may require $\mathrm{Zn}$ fertilization in the study area. The mean concentration of $\mathrm{Zn}$ recorded in the study area was below the WHO/FAO (2001) ecological risk permissible limit of $300 \mathrm{mgkg}^{-1}$ for soils.

Cadmium $(\mathrm{Cd})$, Chromium $(\mathrm{Cr})$, Copper $(\mathrm{Cu})$ and Lead $(\mathrm{Pb})$ were not detected in the soils of the study area as such they pose no threat to the environment (Table 1).

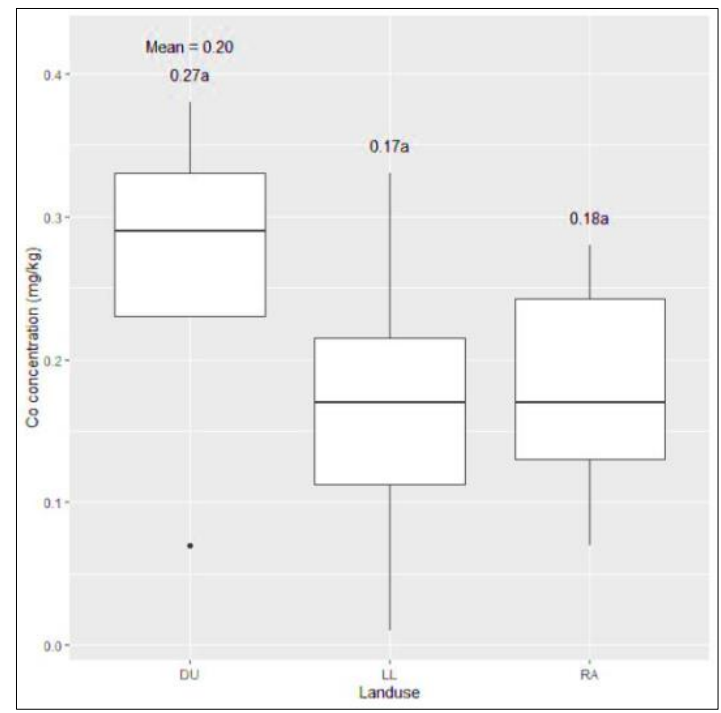

Figure-6. Cobalt (Co) concentration $\left(\mathrm{mg} \mathrm{kg}^{-1}\right)$ of the Soils under Landuse types (Dry Upland Farm (DU), Lowland Farm (LL) and Residential Area (RA)) 


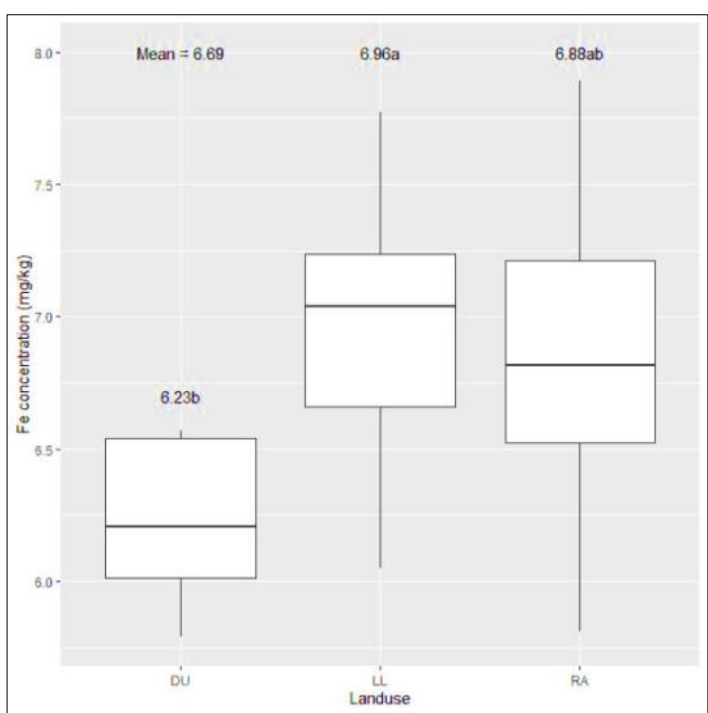

Figure-7. Iron $(\mathrm{Fe})$ concentration $\left(\mathrm{mg} \mathrm{kg}^{-1}\right)$ of the Soils under Landuse types (Dry Upland Farm (DU), Lowland Farm (LL) and Residential Area (RA))

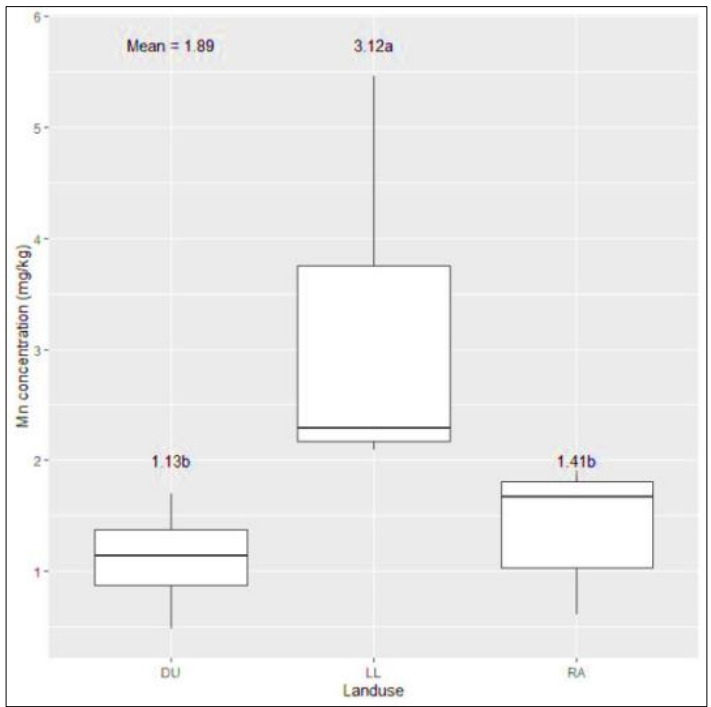

Figure-8. Manganese (Mn) concentration $\left(\mathrm{mg} \mathrm{kg}^{-1}\right)$ of the Soils under Landuse types (Dry Upland Farm (DU), Lowland Farm (LL) and Residential Area (RA)) 


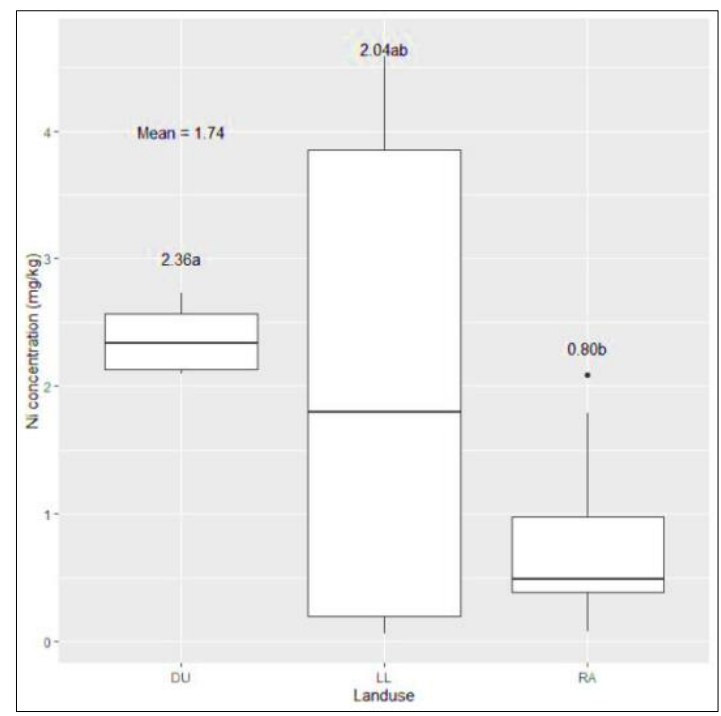

Figure-9. Nickel (Ni) concentration $\left(\mathrm{mg} \mathrm{kg}^{-1}\right)$ of the Soils under Landuse types (Dry Upland Farm (DU), Lowland Farm (LL) and Residential Area (RA))

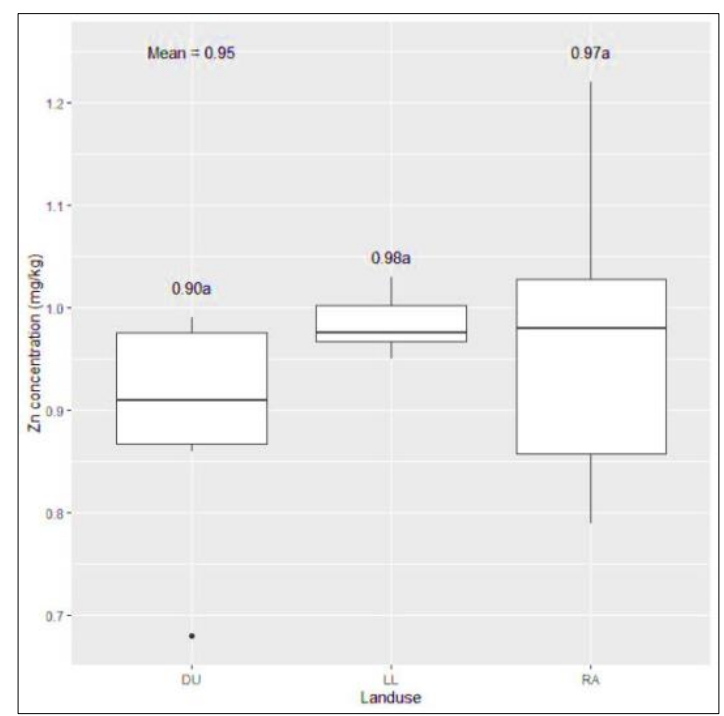

Figure-10. Zinc $(\mathrm{Zn})$ concentration $\left(\mathrm{mg} \mathrm{kg}^{-1}\right)$ of the Soils under Landuse types (Dry Upland Farm (DU), Lowland Farm (LL) and Residential Area (RA))

The soil depth $(0-15$ and $15-30 \mathrm{~cm})$ was found not to have significant influence on all the measured soil variables (Table 2), but clay fraction showed high coefficient variability (37.50\%) and in the concentrations elements such as Co (48.94), $\mathrm{Mg}$ (40.76\%), Mn (67.95\%) and $\mathrm{Ni}(78.87 \%)$. 
Table-2. Effect of Soil Depth on the Soil Properties

\begin{tabular}{lccccc}
\hline \multicolumn{1}{c}{ Soil Properties } & $0-15 \mathrm{~cm}$ & $15-30 \mathrm{~cm}$ & Mean & SE & CV $(\%)$ \\
\hline Sand $(\%)$ & 74.5 & 77.5 & 76 & 2.66 & 8.58 \\
Silt $(\%)$ & 14.33 & 13.67 & 14 & 1.68 & 29.35 \\
Clay $(\%)$ & 11.17 & 8.83 & 10 & 1.53 & 37.5 \\
Textural class & $\mathrm{SL}$ & $\mathrm{SL}$ & & & \\
Bulk Density $\left(\mathrm{g} \mathrm{cm}^{-3}\right)$ & 1.58 & 1.66 & 1.62 & 0.05 & 7.6 \\
pH & 6.76 & 6.85 & 6.81 & 0.19 & 6.87 \\
Calcium $\left(\mathrm{mgkg}^{-1}\right)$ & 2.91 & 3.23 & 3.07 & 0.23 & 18.32 \\
Cadmium $\left(\mathrm{mgkg}^{-1}\right)$ & $\mathrm{ND}$ & $\mathrm{ND}$ & $\mathrm{ND}$ & & \\
Cobalt $\left(\mathrm{mgkg}^{-1}\right)$ & 0.19 & 0.22 & 0.20 & 0.04 & 48.94 \\
Chromium $\left(\mathrm{mgkg}^{-1}\right)$ & $\mathrm{ND}$ & $\mathrm{ND}$ & $\mathrm{ND}$ & & \\
Copper $\left(\mathrm{mgkg}^{-1}\right)$ & $\mathrm{ND}$ & $\mathrm{ND}$ & $\mathrm{ND}$ & & \\
Potassium $\left(\mathrm{mgkg}^{-1}\right)$ & 0.52 & 0.51 & 0.51 & 0.01 & 6.61 \\
Iron $\left(\mathrm{mgkg}^{-1}\right)$ & 6.92 & 6.46 & 6.69 & 0.23 & 8.53 \\
Magnesium $\left(\mathrm{mgkg}^{-1}\right)$ & 2.85 & 3.48 & 3.17 & 0.53 & 40.76 \\
Nickel $\left(\mathrm{mgkg}^{-1}\right)$ & 1.71 & 1.76 & 1.73 & 0.56 & 78.87 \\
Lead $\left(\mathrm{mgkg}^{-1}\right)$ & $\mathrm{ND}$ & $\mathrm{ND}$ & $\mathrm{ND}$ & & \\
Zinc $\left(\mathrm{mgkg}^{-1}\right)$ & 0.98 & 0.92 & 0.95 & 0.04 & 11.03 \\
\hline L lowland, RA = residential & area, DU = dry & upland, SE = standard error, CV = coefficient of variation, ND = not detected
\end{tabular}

\section{CONCLUSION}

The results showed that five of the elements analyzed (Co, Fe, $\mathrm{Mn}, \mathrm{Ni}$ and $\mathrm{Zn}$ ) were present in soil samples at the three landuses sites, while $\mathrm{Cu}, \mathrm{Cr}, \mathrm{Cd}$, and $\mathrm{Pb}$ were not detected. Significant differences were found between the land uses in the concentrations of $\mathrm{Fe}, \mathrm{Mn}$ and $\mathrm{Ni}$, higher values were recorded under LL except for Ni while lower concentrations were mostly recorded in DU. Generally, the concentrations of the elements in soils under varying landuses studied are within the required concentrations for crop production except for $\mathrm{Zn}$. The elemental concentrations in the soils do not exceed the maximum permissible concentration limit according to USEPA (2002) and WHO/FAO (2001) guidelines.

There is a need for regular assessment and monitoring of these elements in the study area in order to sustain agricultural production and protect the environment as well as human and animal health from the hazards that elevated levels of the elements may pose. The variability of the concentrations under difference landuses may require site specific management. Addition of organic matter (OM) can be useful in improving soil physical condition, reduce compaction, supply plant nutrients and maintain elemental balance in the soil.

\section{ACKNOWLEDGEMENT}

Authors acknowledged the TETFUND Nigeria through Federal University, Gashua, Nigeria for providing the financial support to carry out the above research.

\section{CONFLICTS OF INTEREST}

The authors declare no conflict of interest.

\section{REFERENCES}

1. Adagunodo, L.A., Sunmonu, T.A. and Emetere, M.E. (2018). Heavy metals' data in soils for agricultural activities. Data in Brief, 18: 1847-1855. https://doi.org/10.1016/j.dib.2018.04.115
2. Agbenin, J.O., Danko, M. and Welp, G. (2009). Soil and vegetable compositional relationships of eight potentially toxic metals in urban garden fields 
from northern Nigeria. J. Sci. Food Agric., 89: 4954. doi:10.1002/jsfa.3409

3. Alhassan, I., Gashua, A.G., Dogo, S., Sani, M. (2018). Physical properties and organic matter content of the soils of Bade in Yobe State, Nigeria. Int. J. Agric. Environ. Food Sci., 2(4), 160-163. DOI: $10.31015 /$ jaefs. 18027

4. Arshad, M. A., Lowery, B. \& Grossman, B. (1996). Physical Tests for Monitoring Soil Quality. In: Doran, J. W., Jones, A. J. (Eds.). Methods for assessing soil quality. Madison, WI

5. Bhatt, R. (2019). Importance of Soil Texture. (retrieved from https://www.scribd.com on 30 December, 2019)

6. Chaudhari, P.R., Ahire, D.V., Ahire, V.D., Chkravarty, M. and Maity, S. (2013). Soil Bulk Density as related to Soil Texture, Organic Matter Content and available total Nutrients of Coimbatore Soil. International Journal of Scientific and Research Publications, 3(2):1-8

7. Dawaki, U.M., Dikko, A.U., Noma, S.S. and Aliyu, U. (2013). Heavy Metals and Physicochemical Properties of Soils in Kano Urban Agricultural Lands. Nigerian Journal of Basic and Applied Science, 21(3): 239-246. Doi.org/10.4314/inbas.v21i3.9

8. Deckers, J., Dondeyne, S., Vandekerckhoven, L. and Raes, D. (1995). Major soils and their formation in the West African Sahel. In: Meizan, K.M., C.M.S. Wopereis, M. Dungkuhn, J. Decker's \& T.R. Randokph (Eds). Irrigated rice in Sahel: prospects for sustainable development. West African Rice Development Association, WARDA/ADRAO, Saint Louis, Senegal, 23-35.

9. Estefan, G., Sommer, R. and Ryan, J. (2013). Methods of Soil, Plant and Water Analysis: A manual for the West Asia and North Africa region, $3^{\text {rd }}$ ed. ICARDA, Beirut, Lebanon. P 243

10. Eswaran, H., Lal, R. and Reich, P.F. (2001). Land degradation: an overview. In: Bridges EM, Hannam ID, Oldeman LR et al.(eds) Responses to land degradation. Proc. 2nd. International
Conference on land degradation and desertification, Khon Kaen, Thailand. Oxford, New Delhi

11. Federal Environmental Protection Agency [FEPA](1991). National Guidance and Standards for Industrial Effluents, Gaseous Emissions and Hazardous Waste Management in Nigeria. Federal Government, Nigeria.

12. Guodong L., Simonne, E. H. and Yuncong, L. (2020). Nickel Nutrition in Plants. UF/IFAS Extension series of the Horticultural Sciences Department, no.HS1191. Available at https://edis.ifas.ufl.edu.

13. Hengl, T., Leenaars, J. G., Shepherd, K. D., Walsh, M. G., Heuvelink, G. B., Mamo, T., et al. (2017). Soil nutrient maps of Sub-Saharan Africa: Assessment of soil nutrient content at $250 \mathrm{~m}$ spatial resolution using machine learning. NutrientNutrient Cycling in Agroecosystems, 109(1), 77-102.

14. Horneck, D.A., Sullivan, D.M., Owen, J.S. and Hart, J.M. (2011). Soil Test Interpretation Guide. EC 1478. Corvallis, OR: Oregon State University Extension Service

15. Hunt, N. and Gilkes, R. (1992). Farm Monitoring Handbook. The University of Western Australia: Nedlands, WA.

16. Ibrahim A.K., Usman A., Abubakar, B. and Aminu, U.H. (2011). Extractable micronutrients status in relation to other soil properties in Billiri Local Government Area, Gombe State, Journal of Soil Science and Environmental Management. 3(10):282-285.

17. Idera, F., Omotola, O., Adedayo, A. and Paul, U. J. (2015). Comparison of Acid Mixtures Using Conventional Wet Digestion Methods for Determination of Heavy Metals in Fish. Journal of Scientific Research \& Reports. 8(7): 1-9. DOI: 10.9734/JSRR/2015/19717

18. Kabata-Pendias, A. (2011). Trace Elements in Soils and Plants, CRC Press, Boca Raton, Florida, USA. 
19. Kihara, J., Bolo, P., Kinyua, M., Rurinda, J. and Piikki, K. (2020). Micronutrient deficiencies in African soils and the human nutritional nexus: opportunities with staple crops. Environ Geochem Health (2020) 42:3015-3033. https://doi.org/10.1007/s10653-019-00499-w.

20. Lal, R. (2006). Encyclopedia of Soil Science. Taylor and Francis, Florida, USA.

21. Ma, Y. and Hooda, P. S. (2010). Chromium, Nickel and Cobalt In: P. S. Hooda (Ed.). Trace Elements in Soils. John Wiley \& Sons Ltd, United Kingdom. pp596

22. McKenzie, N.J., Jacquier, D.J., Isbell, R.F. and Brown, K.L. (2004). Australian Soils and Landscapes: An Illustrated Compendium. CSIRO Publishing: Collingwood, Victoria.

23. Mulima I. M., Ismaila M. Shafiu, M. I. and Benisheikh, K. M. (2015). Status and Distribution of Some Available Micronutrients in Sudan and Sahel Savanna Agro-Ecological Zones of Yobe State, Nigeria. Journal of Environmental Issues and Agriculture in Developing Countries, 7(1):18-29

24. Munkholm, L.J., Esu, I. and Moberg, J.P. (1993). Trace elements in some northern Nigerian soils. Commun. Soil Sci. Plant Anal. 24:657-672.

25. Mustapha, S., Voncir, N., Umar, S. and Abdulhamid, N. S. (2011). Status and Distribution of some Available Micronutrients in Haplic usterts of Akko Local Government Area, Gombe State, Nigeria. International Journal of Soil Science, 6(4):267-274

26. Negasa, T., Ketema, H., Legesse, A., Sisay, M., \& Temesgen, H. (2017). Variation in soil properties under different land use types managed by small-holder farmers along the toposequence in southern Ethiopia. Geoderma, 290, 40-50.

27. Ogundele, D.T., Adio, A.S. and Oludele, O.E. (2015). Heavy Metal Concentrations in Plants and Soil along Heavy Traffic Roads in North Central Nigeria. Journal of Environmental and Analytical Toxicology. 5(6):1-5. Doi.10.4172/21610525.1000334
28. Oluwadare, D.A., Voncir, N., Mustapha, S. and Mohammed, G.U. (2013). Evaluation and Enhancement of Available Micronutrients Status of Cultivated Soil of Nigeria Guinea Savanna Using Organic and Inorganic Amendments. IOSR Journal of Agriculture and Veterinary Science, 3(5):62-68.

29. Oyinlola, E.Y. and Chude, V.O. (2010). Status of available nutrients of the basement complex rock-derived alfisols in northern Nigeria savanna. Tropical and Subtropical Agroecosystems, 12(2):229-237.

30. R Core Team (2019). R: A language and environment for statistical computing. $\mathrm{R}$ Foundation for Statistical Computing, Vienna, Austria. URL https://www.R-project.org/.

31. Shukla, U. C. and Gupta, B. L. (1975). "Response of Mn application and evaluation of chemical extractants to determine available $\mathrm{Mn}$ in some arid brown soils of Haryana", Journal of the Indian Society of Soil Science, 23(3):357-364

32. Srivastava, j. P., Tamboli, P. M., English, J. C., Lal, R. and Stewart, B. A. (1993). Conserving Soil Moisture and Fertility in the Warm Seasonally Dry Tropics. World Bank Technical Paper number 221

33. Tabi, F.O. and Ogunkunle, A.O. (2007). Spatial variation of some soil physico-chemical properties of an Alfisol in southwestern Nigeria. Nigerian Journal of Soil and Environmental Resources, 7:82-91.

34. Tabor, N. J., Myers, T. S. \& Michel, L.A. (2017). Sedimentologist's Guide for Recognition, Description, and Classification of Paleosols.

35. Tilahun, G. (2007). Soil Fertility Status as Influenced by different Land Uses in Maybar Areas of South Wello Zone, North Ethiopia. Master of Science in Agriculture (Soil Science) Thesis Haramaya University, Ethiopia.

36. Ufot, U.O., Iren, O.B. and Chikere Njoku, C.U. (2016). Effects of land use on soil physical and chemical properties in Akokwa area of Imo State, Nigeria. International Journal of Life Sciences Scientific Research 2(3): 273-278. 
37. US Environmental Protection Agency [USEPA] (2002). Supplemental guidance for developing soil screening levels for superfund sites. Office of Solid Waste and Emergency Response, Washington, D.C. http://www.epa.gov/superfund/health/conmedia/so il/index.htm

38. Weil, R. R. and Brady, N. C. (2017). Nature and Properties of Soils, $15^{\text {th }}$ edition. Pearson Education, Inc. Delhi, India.

39. WHO/FAO. (2001). Codex alimentarius commission. Food additives and contaminants. Joint FAO/WHO Food Standards Programme, ALINORM 10/12A. Retrieved on 6 September 2020 from www.transpaktrading.com/static/pdf/research/ache mistry/introTofertilizers.pdf 